F. Pranovi $\cdot$ S. Libralato $\cdot$ S. Raicevich

A. Granzotto · R. Pastres · O. Giovanardi

\title{
Mechanical clam dredging in Venice lagoon: ecosystem effects evaluated with a trophic mass-balance model
}

Received: 12 May 2002/ Accepted: 8 March 2003/Published online: 7 May 2003

(C) Springer-Verlag 2003

\begin{abstract}
Harvesting of the invasive Manila clam, Tapes philippinarum, is the main exploitative activity in the Venice lagoon, but the mechanical dredges used in this free-access regime produce a considerable disturbance of the lagoon ecosystem. An ecosystem approach to study the complex effects of clam harvesting was implemented using a trophic mass-balance model. The trophic relations in the ecosystem were quantified with a mixed trophic impact analysis and further evaluated by considering different explanations for the "Tapes paradox", which consists of the apparent population enhancement of Manila clams by dredging and the apparent nutritional advantages that this species receives from re-suspended organic matter. The key-role played by this introduced species is highlighted by a network analysis that indicates a "wasp-waist control" of the system by Manila clams. The model constructed to characterise the present state of the Venice lagoon ecosystem is compared with models produced for a reconstructed past lagoon and a projected future lagoon. The future model was obtained by simulating the elimination of clam dredging in 10 years. The three different models were compared using thermodynamic and informational indices. Simulating the elimination of clam dredging produced a $33 \%$ increase in artisanal fishery catches, carried out by means of static gears, even with no change in fishing effort. These simulations also forecast an increase in the mean trophic level of the artisanal fishery
\end{abstract}

Communicated by R. Cattaneo-Vietti, Genova

F. Pranovi $(\bowtie) \cdot S$. Libralato $\cdot$ S. Raicevich $\cdot$ A. Granzotto Dipartimento Scienze Ambientali, Univ. Ca' Foscari, 2737/B Castello, 30122 Venice, Italy

E-mail: fpranovi@unive.it

Fax: + 39-41-5281494

R. Pastres

Dipartimento Chimica Fisica, Univ. Ca' Foscari, 2737/B Castello, 30122 Venice, Italy

O. Giovanardi

Istituto Centrale per la Ricerca Applicata al Mare, ICRAM, Chioggia (VE), Italy catches as a positive effect of eliminating mechanical clam harvesting.

\section{Introduction}

Living marine resources world-wide are sustaining unprecedented levels of anthropogenic pressure; many stocks have collapsed and many habitats are severely threatened (NRC 1995; Botsford et al. 1997; Jackson 2001; Jackson et al. 2001; Watson and Pauly 2001). Despite progress in fisheries management science, the debate at the start of the new millennium is whether or not we can save such resources from (commercial) extinction and allow ecosystems to maintain their main functions (Caddy and Cochrane 2001). The diversity of biological communities plays a key-role in determining the functioning of ecosystems (Laureau et al. 2001; Kinzing et al. 2002), and this is realised through trophic interactions and their indirect effects on other ecosystem processes (Duffy 2002; Naeem 2002). Changes in biodiversity at one trophic level are known to affect biodiversity in adjacent levels and beyond, and these will also feed back on the ecosystem (Raffaelli et al. 2002).

In recent years, scientists have focused their attention on the impact of fishing disturbance on the trophic structure of marine communities. Indeed, exploited marine living resources are linked through complex webs of functional relationships with other organisms in their ecosystems. Consequently, the food web configuration of exploited ecosystems is the product of both direct and indirect effects of fisheries, in addition to oceanographic changes and cycles, pollution and other disturbances (Cloern 2001; Jackson et al. 2001; Jennings et al. 2001). Furthermore, fisheries directly affect the carrying capacity of marine ecosystems by altering the structure of food webs and changing their potential productivity (Christensen and Pauly 1998). Recently, Pauly et al. (1998) revealed a general decline in mean trophic level of marine landings globally and in many regions. 
All this has been confirmed by controlled experiments (Menge 1995) and indirect inferences from fishery (Botsford et al. 1997; Pinnegar et al. 2000) and historical data (Dayton et al. 1998; Jackson et al. 2001), which indicate that strong top-down forces are common in marine food webs and often have far-reaching indirect effects on ecological structure and functioning. Therefore the structure and complexity of food webs is revealed to be a "focus point" in the study of the propagation of indirect effects of disturbance in ecosystems (Fox and Olsen 2000).

Mass-balance models, such as Ecopath (Christensen and Pauly 1993), could be useful tools, on the one hand, to investigate effects on the ecosystem structure of the biological community changes induced by external sources of disturbance (e.g. fishing activity) and, on the other hand, to identify the species which play a key-role in driving ecosystem processes. This kind of model gives a static representation of the energy flows of ecosystems, including the trophic relations among organisms and the outgoing flow due to fisheries. On the whole, these flows represent the network structure of the food web (Christensen et al. 2000). The major advantage of this network approach is its suitability to the application of a broad field of theories that are useful for ecosystem studies. These include thermodynamic concepts, information theory, trophic level description and network analysis (Müller 1997). The steady-state picture of trophic flows of the ecosystem is the baseline for the development of dynamic simulations, which could help to assess the suitability of different management activities by simulating dynamic community responses to human-induced changes, such as fishing effort and protected areas (Walters et al. 1997). This can, in turn, lead to the development of policies aimed at implementing ecosystem management principles (Jørgensen 1992).

Venice lagoon is the largest Mediterranean lagoon $\left(>400 \mathrm{~km}^{2}\right)$, and it is subjected to many kinds of anthropogenic pressure. It is surrounded by a large industrial and tourist port, oil refineries and urban agglomerations.

Until the end of the 1980s, biological resources were exploited only by means of artisanal fishery (mainly static gears), but clam harvesting became the main exploitative activity after the 1983 invasion of Tapes philippinarum (Cesari and Pellizzato 1985). Since the beginning of the 1990s, Manila clams have been harvested by means of mechanical dredges. At the beginning of the 1990s, only a few boats used hydraulic dredges, but by the middle of the 1990s there were $>100$ such boats (Pranovi and Giovanardi 1994). Presently, fishermen have adopted a new fishing technique, and almost 600 boats use mechanical dredges. These dredges, locally named "rusca" (Provincia di Venezia 2000), collect $>50 \%$ (40,000 tons) of the entire Italian Manila clam catch.

All this dredging causes a great disturbance in the lagoon ecosystem (Da Ponte 2001), which could be considered a sensitive area. This conflict requires quick adoption of effective management strategies to reverse the severe modification of this ecosystem (Provincia di Venezia 2000).

An Ecopath model describing the Venice lagoon ecosystem was set up to investigate the effects of mechanical clam harvesting, taking into account both artisanal fishery and mechanical clam dredging.

The aims of the study were:

1. to describe the changes in the biological community due to a reduction to zero of the mechanical clam harvesting in the coming 10 years,

2. to evaluate the changes in the lagoon ecosystem in the past 10 years, after the introduction of Manila clam and since the beginning of mechanical exploitation,

3. to compare the three different stages (present, past and future) of the Venice lagoon ecosystem to assess both direct and indirect effects of mechanical clam harvesting on the structure of the trophic web, and

4. to identify the species which, at present, play a keyrole in driving lagoon ecosystem processes.

\section{Materials and methods}

Mechanical clam harvesting

At present, in the Venice lagoon, clam harvesting is carried out mainly by means of a gear locally called "rusca", which consists of an iron cage, $60 \mathrm{~cm}$ wide, and a net bag in which the clams are collected. The digging action is performed by means of an outboard engine propeller $(25 \mathrm{hp}$ ), which, located on the side of the boat, produces a water flow directed at the sediment. The propeller wash suspends bottom sediments and clams into a plume in the water column. The clams are then collected in the net bag.

Modeled area and trophic group aggregation

The Manila clam, Tapes philippinarum (Adams \& Reeve, 1850), is distributed throughout the Venice lagoon, but dredging grounds are mainly concentrated in its central basin, where clams are most abundant (Casale et al. 2001). We estimate that the dredging grounds cover $134 \mathrm{~km}^{2}$, which is approximately one-third of the total area of Venice lagoon (about $437 \mathrm{~km}^{2}$ ). Input parameters for the model were estimated using biological data from the areas subjected to clam dredging. These data were organised to estimate the average parameters and biomasses for the exploited areas, leading to a model that represents the "average exploited habitat."

The trophic groups were identified based on three criteria:

1. similar biological features (growth, mortality and metabolic rates),

2. similar trophic characteristics, and

3. importance as target species for lagoon fisheries.

As a result, the biological components were aggregated into 25 functional groups; bottom sediment and suspended/dissolved organic matter in the water column made up two detritus groups, for a total of 27 groups (Table 1). This model also accounts for artisanal fishery, which exploits mainly fish species and is carried out by means of traditional static gears (Granzotto et al. 2000), and for mechanical clam harvesting, which is characterised by a high discard versus commercial ratio and produces a conspicuous impact on bottom sediments (Da Ponte 2001). 
Table 1 Trophic groups identified in the areas of the Venice lagoon in 1998, where mechanical harvesting of the Manila clam (Tapes philippinarum) is concentrated. Species are grouped based on similarities in metabolic rates (growth, respiration, assimilation), trophic behaviour (similar prey) and fisheries (target for the same fishery). Biomasses $(B)$, production rates $(P / B)$, consumption rates $(Q / B)$, ecotrophic efficiency $(E E)$, production/consumption $(P / Q)$ and assimilation rates $(U n / Q)$ used in the mass-balance model of the 1998 Venice lagoon. Values estimated by Ecopath are in parentheses (superscripts: $A^{*}$ Curiel, personal communication; $B$ Flindt et al. 1997; $C$ Sorokin et al. 1996; $D$ Sorokin et al. 1999; $E$ Carrer and Opitz 1999; $F$ Da Ponte 2001; $G$ Casale et al. 2001; $H$ Giovanardi, unpublished data; $I$ Franzoi, personal communication; $L$ virtual population analysis estimates; $M$ Sorokin et al. 1996; $N$ Sfriso and Marcomini 1996; $O$ Sfriso and Ghetti 1998; $P$ Christian et al. 1993, Buia et al. 2000; $Q$ Brey 1990; $R$ Sorokin and Giovanardi 1995, Solidoro et al. 2000; $S^{*}$ Auteri et al. 1993; $T$ Froese and Pauly 2003; U Christensen and Pauly 1993)

\begin{tabular}{|c|c|c|c|c|c|c|c|}
\hline & Description & $\mathrm{B}\left(\mathrm{kJ} \mathrm{m}^{-2}\right)$ & $\mathrm{P} / \mathrm{B}\left(\right.$ year $\left.^{-1}\right)$ & $\mathrm{Q} / \mathrm{B}\left(\right.$ year $\left.^{-1}\right)$ & $\mathrm{EE}$ & $\mathrm{P} / \mathrm{Q}$ & $\mathrm{Un} / \mathrm{Q}$ \\
\hline Ulvales & Ulva rigida & $1,480.50^{\mathrm{A}}$ & $11.68^{\mathrm{N}}$ & & $(0.008)$ & & \\
\hline Seagrasses & $\begin{array}{l}\text { Zostera marina, Z. noltii, } \\
\text { Cymodocea nodosa }\end{array}$ & 1.00 & $6.81^{\mathrm{N}, \mathrm{O}}$ & & $(0.005)$ & & \\
\hline Other macroalgae & $\begin{array}{l}\text { Chaetomorpha sp., Cladophora sp., } \\
\text { Gracilaria verrucosa }\end{array}$ & $421.34^{\mathrm{B}}$ & $16.80^{\mathrm{E}}$ & & $(0.022)$ & & \\
\hline Epiphytes & & 1.00 & $273.75^{\mathrm{P}}$ & & $(0.612)$ & & \\
\hline Phytoplankton & & $2.55^{\mathrm{C}, \mathrm{D}}$ & $759.10^{\mathrm{C}, \mathrm{D}}$ & & $(0.800)$ & & \\
\hline Bacterioplankton & & $12.14^{\mathrm{C}, \mathrm{D}}$ & $163.01^{\mathrm{C}, \mathrm{D}}$ & $336.00^{\mathrm{E}}$ & $(0.773)$ & $(0.485)$ & $0.10^{\mathrm{U}}$ \\
\hline Zooplankton & & $5.00^{\mathrm{C}, \mathrm{D}}$ & $117.07^{\mathrm{C}, \mathrm{D}}$ & $(585.34)$ & $(0.825)$ & $0.200^{\mathrm{U}}$ & $0.50^{\mathrm{U}}$ \\
\hline Micro-meiobenthos & Protozoa, Nematoda, Copepoda & $187.68^{\mathrm{E}}$ & $(13.70)$ & $68.52^{\mathrm{E}^{\prime}}$ & $(0.407)$ & $0.200^{\mathrm{U}}$ & $0.40^{\mathrm{U}}$ \\
\hline Macrobenthos detritivorous & Polichaeta, Amphipoda, Isopoda & $76.48^{\mathrm{F}}$ & $5.23^{\mathrm{F}, \mathrm{Q}}$ & $18.00^{\mathrm{E}}$ & $(0.837)$ & $(0.290)$ & $0.40^{\mathrm{U}}$ \\
\hline Macrobenthos herbivorous & Gastropoda, Amphipoda & $0.07^{\mathrm{F}}$ & $1.66^{\mathrm{F}, \mathrm{Q}}$ & $(8.32)$ & $(0.901)$ & $0.200^{\mathrm{U}}$ & $0.40^{\mathrm{U}}$ \\
\hline Macrobenthos filter-feeders & Bivalvia (without T. philippinarum) & $35.90^{\mathrm{F}}$ & $4.36^{\mathrm{F}, \mathrm{Q}}$ & $(21.79)$ & $(0.804)$ & $0.200^{\mathrm{U}}$ & $0.30^{\mathrm{U}}$ \\
\hline Manila clam juv. & T. philippinarum juveniles & $29.78^{\mathrm{G}, \mathrm{H}}$ & $6.20^{\mathrm{R}}$ & $(22.98)$ & $(0.472)$ & $0.270^{\mathrm{R}}$ & $0.40^{\mathrm{R}}$ \\
\hline Manila clam comm. & T. philippinarum commercial size & $250.48^{\mathrm{G}, \mathrm{H}}$ & $6.20^{\mathrm{R}}$ & $(22.98)$ & $(0.253)$ & $0.270^{\mathrm{R}}$ & $0.40^{\mathrm{R}}$ \\
\hline Macrobenthos mixed-feeders & Anthozoa, Decapoda & $143.93^{\mathrm{F}}$ & $4.45^{\mathrm{F}, \mathrm{Q}}$ & $9.60^{\mathrm{E}^{\prime}}$ & $(0.466)$ & $(0.463)$ & $0.20^{\mathrm{U}}$ \\
\hline Macrobenthos carnivorous & Decapoda, Gastropoda, Polychaeta & $15.76^{\mathrm{F}}$ & $2.67^{\mathrm{F}, \mathrm{Q}}$ & $(13.36)$ & $(0.909)$ & $0.200^{\mathrm{U}}$ & $0.20_{\mathrm{S}}^{\mathrm{U}}$ \\
\hline Mullets juv. & Mugilidae juveniles & $0.04^{\mathrm{I}}$ & $1.74^{\mathrm{S}}$ & $23.45^{\mathrm{S}}$ & $(0.042)$ & $(0.074)$ & $0.50^{\mathrm{S}}$ \\
\hline Mullets ad. & Mugilidae adults & $3.39^{\mathrm{L}}$ & $0.60^{\mathrm{S}}$ & $23.50^{\mathrm{S}}$ & $(0.938)$ & $(0.025)$ & $0.50^{\mathrm{S}}$ \\
\hline Sand smelt & Atherina boyeri & $6.10^{\mathrm{L}}$ & $1.70^{\mathrm{S}}$ & $15.65^{\mathrm{S}}$ & $(0.773)$ & $(0.109)$ & $0.20^{\mathrm{S}}$ \\
\hline Grass goby & Zosterisessor ophiocephalus & $6.27^{\mathrm{L}}$ & $1.94^{\mathrm{S}}$ & $6.70^{\mathrm{T}}$ & $(0.493)$ & $(0.290)$ & $0.20^{\mathrm{S}}$ \\
\hline $\begin{array}{l}\text { Nekton carnivorous } \\
\text { benthic feeders }\end{array}$ & $\begin{array}{l}\text { Soleasp., Sepia sp., Gobiidae, } \\
\text { Plathychthys sp. }\end{array}$ & $5.14^{\mathrm{L}}$ & $(1.30)$ & $6.48^{\mathrm{E}}$ & $(0.857)$ & $0.200^{\mathrm{U}}$ & $0.26^{\mathrm{E}}$ \\
\hline Seabream juv. & Sparus auratus juveniles & $0.04^{\mathrm{I}}$ & $2.06^{\mathrm{S}}$ & $8.25^{\mathrm{S}}$ & $(0.038)$ & $(0.250)$ & $0.20_{\mathrm{S}}^{\mathrm{S}}$ \\
\hline Seabream ad. & S.auratus adults & $1.23^{\mathrm{L}}$ & $0.99^{\mathrm{S}}$ & $4.74^{\mathrm{S}}$ & $(0.725)$ & $(0.209)$ & $0.20^{\mathrm{S}}$ \\
\hline Seabass juv. & Dicentrarchus labrax juveniles & $0.0004^{\mathrm{I}}$ & $1.52^{\mathrm{S}}$ & $6.08^{\mathrm{S}}$ & $(0.000)$ & $(0.250)$ & $0.20^{\mathrm{S}}$ \\
\hline Seabass ad. & D.labrax adults & $8.82^{\mathrm{L}}$ & $0.57^{\mathrm{S}}$ & $5.13^{\mathrm{S}}$ & $(0.869)$ & $(0.111)$ & $0.20^{\mathrm{S}}$ \\
\hline Birds & Phalacrocorax carbo sinensis & $0.04^{\mathrm{E}}$ & $(4.22)$ & $21.12^{\mathrm{E}}$ & $(0.000)$ & $0.200^{\mathcal{U}}$ & $0.20^{\mathrm{E}}$ \\
\hline SOM\&LOM & Suspended and labile organic matter & $214.08^{\mathrm{C}, \mathrm{D}}$ & & & $(1.000)$ & & \\
\hline Detritus & Bottom sediment & $23,638.93^{\mathrm{M}}$ & & & $(0.446)$ & & \\
\hline
\end{tabular}

Ecopath with Ecosim model

Energy balance is calculated for each trophic group $i$ of the network by fixing the equivalence between its production $\left(P_{i}\right)$, and its outgoing energy flows, which are comprised of the predation mortality $\left(M 2_{i, j}\right)$ caused by the biomass of all predators $\left(B_{j}\right)$, the net migration $\left(E_{i}\right)$ from the system and the biomass removed by fisheries (catches, $Y_{i}$ ). The balance also takes into account the accumulation of biomass in the system $\left(B A_{i}\right)$ and other types of mortality $\left(1-E E_{i}\right)$, so that:

$P_{i}=\sum_{j} B_{j} \cdot M 2_{i, j}+E_{i}+Y_{i}+B A_{i}+P_{i} \cdot\left(1-E E_{i}\right)$

The production is calculated from the $\mathrm{P} / \mathrm{B}$ ratio and a biomass estimate, while predation mortalities are obtained from the consumption rate of the predator $\left(Q / B_{j}\right)$ and the proportion of prey $i$ in its diet $\left(D C_{i, j}\right)$. Thus, the previous equation could be written as:

$B_{i} \cdot\left(\frac{P}{B}\right)_{i}=\sum_{j} B_{j}\left(\frac{Q}{B}\right)_{j} \cdot D C_{i, j}+E_{i}+Y_{i}+B A_{i}+B_{i} \cdot\left(\frac{P}{B}\right)_{i} \cdot\left(1-E E_{i}\right)$

A system of linear equations is obtained applying the above equation to all trophic groups in the system. This is solved by Ecopath with Ecosim (EwE), a software package originally developed for modelling fisheries impacts, but with broad application in ecosystem-based management. Ecopath requires several input parameters: diet composition $\left(D C_{i, j}\right)$, assimilation rate (as the fraction of the food consumption not assimilated, $\left.U N / Q_{i}\right)$, migration $\left(E_{i}\right)$, catches $\left(Y_{i}\right)$ and biomass accumulation $\left(B A_{i}\right)$. Moreover, the user can choose to provide only three of the four basic input parameters: biomass $\left(B_{i}\right)$, production rate $\left(P / B_{i}\right)$, consumption rate $\left(Q / B_{i}\right)$ and ecotrophic efficiency $\left(E E_{i}\right)$, allowing the fourth to be estimated (further details on the software in Christensen et al. 2000).

We chose to express the biomasses as energetic currencies (kJ $\mathrm{m}^{-2}$ ), and metabolic ratios are expressed in per year time units; thus, the model describes the energy flows in the trophic network during 1 year. When necessary, weight was converted to energy using energetic density coefficients, while, for macrophytes and epiphytes, dry to wet weight ratios taken from the literature were also applied.

The catches of lagoon fisheries were modelled according to two different fleets: the artisanal fishery, which uses traditional static gear (e.g. fyke net), and the mechanical clam harvesting (described above). Artisanal fishery was described by means of the outflow from compartments representing caught target and accessory species, and it was assumed to produce no by-catch. For mechanical clam harvesting, in addition to outflow from the group representing the target species, the export of energy was introduced into the model from by-catch groups (mainly macrobenthic groups), representing discards going to the detritus compartment (thus increasing the mortality of the by-catch species).

Moreover, in order to describe the effects of mechanical clam harvesting on sediment resuspension, a "clam fishery resuspension" was introduced, which was modelled as having no landings, but by-catch on bottom sediments that is discarded in the suspended 
organic matter group; the flow was quantified using our experimental data (Da Ponte 2001; Pranovi et al. 2001). This virtual fishery was represented separately in order to distinguish between the effects of the catches and resuspension on the indices.

The mass-balance model was constructed for the year 1998, here considered the "present" status of the ecosystem. Applying a "back to the future" approach (Pitcher 2001), we combined the model structure of 1998 and some of its estimates with data available for the period 1988-1991, obtaining a model representing the end of the 1980s, here called "scenario 1988". From the present-day (1998) model, using the dynamic routine Ecosim, we obtained a "future Venice lagoon model" by changing the clam harvesting mortality to zero. Although the "present" model is inherently more accurate than the resulting "past" and "future" models, the latter represent useful estimates of the possible community states during these other times. Comparison of these three snapshots of the trophic network was conducted.

\section{Parameter estimation for 1998}

Table 1 shows the input data used for the trophic network of the Venice lagoon for the year 1998. The biomasses and other parameters for benthic groups were estimated from sampling and experimental data collected in 1998 at the species level in the central basin of the lagoon (Da Ponte 2001). Production rate $(\mathrm{P} / \mathrm{B})$ estimations for aggregated groups were derived using empirical relationships (Brey 1990).

The biomasses of both juveniles and adults of Tapes philippinarum were estimated using length data (Casale et al. 2001) and applying the allometric relation between length and weight (Solidoro et al. 2000); the production rates for clam groups were estimated from the growth rate and metabolic rates (Sorokin and Giovanardi 1995; Solidoro et al. 2000). Virtual population analysis (VPA) was used to estimate the biomasses of the fish species from landings of adults. For juvenile fishes, a comparison with survey data (Franzoi, personal communication) was also conducted.

Fish catch was estimated based on the 1998 landings for the Venice market, while the harvest of T. philippinarum was estimated using ASAP (1999). The by-catch of the mechanical clam harvesting was estimated based on experimental data (Pranovi et al. 2001). Parameters for other biotic components were taken from published and unpublished data, as reported in Table 1, while the links between juvenile and adult phases for the different species were set through growth parameters taken from published models (Goulletquer et al. 1989; Auteri et al. 1993; Solidoro et al. 2000).

The diet matrix elements $\left(D C_{i, j}\right)$ were defined using studies mainly carried out in Venice lagoon (Barbaro et al. 1983; Francescon et al. 1986; Ceretti et al. 1987; Sorokin and Giovanardi 1995; Carrer and Opitz 1999; Malavasi, unpublished data). Where local data were not available, other sources for the same species were used (Arias 1980; Auteri et al. 1993; Pinnegar and Polunin 1999; Froese and Pauly 2003). When the food item (prey) corresponded to more than one predator group in the model, its fraction was considered proportional to the biomass estimated for each corresponding predator group.

Compared with the other parameters, the diet matrix was considered the most uncertain aspect of the model, and, thus, it was adjusted iteratively by using the Ecoranger tool of the EwE software. During the balancing process, the diet matrix was slightly modified to avoid inconsistent solutions of the energy budget when parameters are randomly changed around the nominal value (Christensen and Walters 2000; Christensen et al. 2000). The small differences between initial values and those obtained after the iterative adjustments allowed assumption of the relatively good estimates included in the diet matrix.

\section{Estimating the past and the future}

The period 1988-1991 was chosen to represent the state of Venice lagoon prior to the spread of the Manila clam and its intensive exploitation. The structure and some parameters from the model of the present state were used as a starting point, but biomasses were estimated for the past period (1988-1991) for most trophic groups (Ulva rigida, phytoplankton, macrobenthic groups) based on Sfriso et al. (1989) and Pranovi (unpublished data). Where biomass estimates for the past were not available, the ecotrophic efficiency estimated by Ecopath for the year 1998 was used as input parameter in the model for the year 1988, that allowed us to estimate the lacking biomasses for the past by using the model. In this way, Ecopath estimated biomasses under the assumption that the fraction of production used within the system is the same in the past and the present. This assumption is reasonable since trophic relations and fishing methods did not change during the studied period. Parameters representing metabolic ratios and food preferences were taken from the baseline model (present, year 1998).

The catches of the artisanal fishery for the past model were estimated using market data for the year 1988, and, although extremely low, the landing of clams was represented in the model using an estimated value taken from ASAP (1999). The catches of non-target species and the resuspension of bottom sediments associated with the clam fishery were estimated to be proportional to the landings across years and, thus, were extrapolated from the present model.

The Ecopath model for the future was obtained using the Ecosim routine applied to the present-day (1998) model, imposing different management policies. Scenarios produced by reduction of fishing mortality (and the reduction of non-target catches and resuspension) were focused on. Since detritus groups in Ecosim could not be used directly to force the dynamics of the system, a mediation function was applied to all groups feeding on suspended organic matter. This function, chosen as a linear relation between the resuspension fishery and predation on SOM\&LOM (suspended and labile organic matter), was set to represent a proportional relationship between sediment resuspension and resuspended food (see Christensen et al. 2000 for further details on mediation function).

In 50-year-long simulations, clam harvesting was set at the actual (1998) fishing pressure for the first 10 years, then it was reduced to zero in different ways: drastic reduction and linear reduction to zero (in intervals of 5 and 10 years); in all cases clam harvesting was maintained at zero for the remaining simulation time. These simulations were conducted with artisanal fishing pressure set at the present (1998) value and maintained unchanged. Although the model shows different behaviour after the start of each different reduction policy scenario, all simulations gave the same final steady state that was taken as an Ecopath model, here considered as the future scenario under the policy of reduction of the mechanical clam harvesting, termed "scenario 2008".

\section{Indices}

In order to compare the status of the three ecosystem scenarios (1988, 1998, 2008), we calculated various indices using EwE.

Mixed trophic impact (MTI; Ulanowicz and Puccia 1990) was calculated by the difference between the diet composition term of the group $j$ in the diet of group $i\left(D C_{i, j}\right)$ and the proportion of the predation on $j$ due to the predator $i\left(F C_{j, i}\right)$ :

$M T I_{i, j}=D C_{i, j}-F C_{j, i}$

The MTI allows us to quantify the direct and indirect impacts that a group (impacting group) has on each of the others (impacted group), through the evaluation of the effect (positive and negative) of an increase of the biomass of the impacting group on the impacted one; it is calculated for each pair of groups in the system, including fisheries (Christensen et al. 2000).

The resulting matrix of MTIs was used to estimate the effect of a group on the whole ecosystem by adding all its MTIs (summed by rows of the MTI matrix) weighted by the inverse of the biomass of impacted groups, thus providing an estimate of the effect of varying the biomass of a particular group on the whole community. 


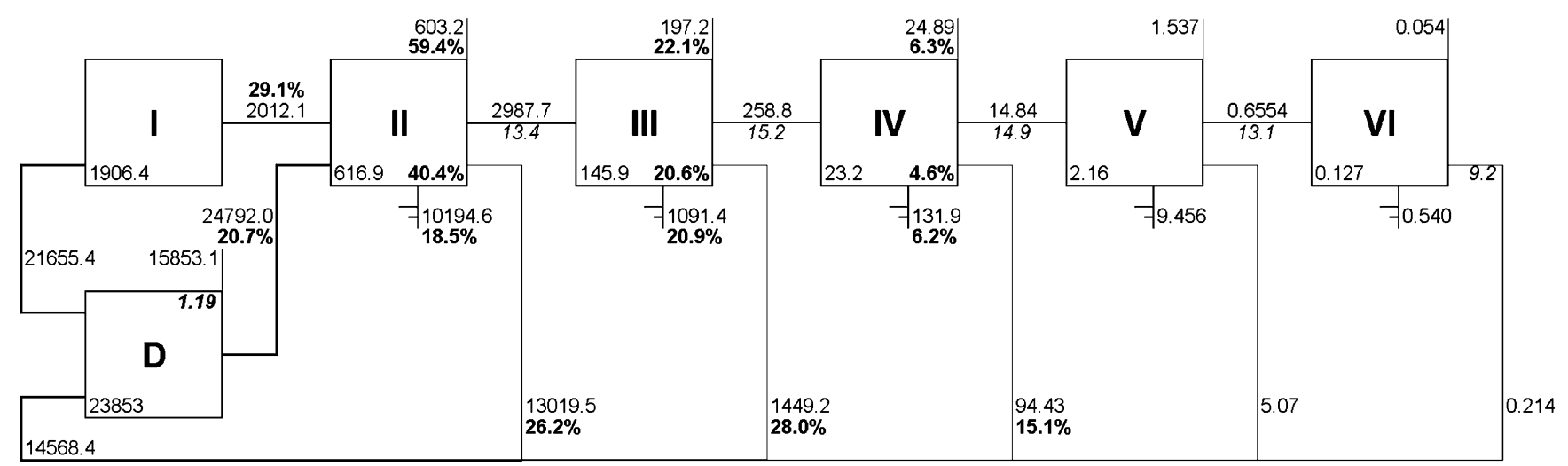

Legenda

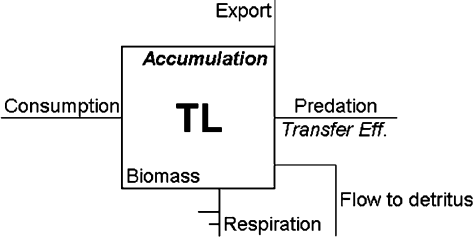

Fig. 1 The complex food web for the present-day (1998) scenario is represented schematically in the form of the Lindeman spine, where biomasses and flows are aggregated into integer trophic levels $(T L)$. Energetic currencies are used $\left(\mathrm{kJ} \mathrm{m}^{-2}\right.$ and $\mathrm{kJ} \mathrm{m}^{-2}$ year ${ }^{-1}$ for biomasses and flows, respectively). At the first level of the chain, the primary producers $(I)$ and detritus $(D)$ are split for clarity. Bold percentages quantify the fraction of biomass and flow related to Manila clams (Tapes philippinarum) at each TL. The high fraction of energetic flows due to this species (especially at TL II) is evidence of its wasp-waist role in the lagoon ecosystem

Following the ecological considerations proposed by Odum (1969), we calculated total net primary production (NPP), total primary production/total respiration $(\mathrm{P} / \mathrm{R})$, net system production (NP), total primary production/total biomass $(\mathrm{Pp} / \mathrm{B})$, total biomass/total throughput (B/T) and total biomass of the system (B) as indices related to ecosystem maturity and stability. We also considered the thermodynamic indices "ascendency" (Ulanowicz 1986), "system overhead" (Monaco and Ulanowicz 1997), and cycling indices as proposed by Finn (1976) and Christensen (1995).

The trophic levels of each of the groups (TL) were computed by the model, thereby providing an estimation of the mean trophic level of the catch (mTL; Pauly et al. 1998). The mTL for the artisanal fishery was calculated separately in order to avoid the obvious lowering effect that the mechanical clam fishery has on the mTL of total catches.

\section{Results}

The present-day (1998) model indicated that the energy required to sustain the Tapes philippinarum population in Venice lagoon is higher than the available plankton food. This result is consistent with results of other authors who have shown non-living suspended organic matter to be a large component of the Manila clam's diet (Sorokin and Giovanardi 1995; Solidoro et al. 2000). Resuspension of sediment and food by mechanical harvesting was thus set at a level adequate to balance T. philippinarum energy requirements (Libralato et al.
2002) and according with experimental measurements (Da Ponte 2001; Pranovi et al. 2001).

Biomasses and flows for the present scenario were aggregated into integer trophic levels (TL, Fig. 1). In this simplified representation of the food web, the standing energy at TL $\mathrm{I}\left(1,906.4 \mathrm{~kJ} \mathrm{~m}^{-2}\right)$ is considerably diminished by TL VI $\left(0.127 \mathrm{~kJ} \mathrm{~m}^{-2}\right)$, and the maximum transfer efficiency occurs at TL III $(15.2 \%$ of production is used by the fisheries and as food for TL IV). The fractions of flows and biomasses flowing through T. philippinarum are also reported as percentage values (in bold on Fig. 1), showing that a high proportion of the biomass of TLs II and III stems from Manila clams (40.4\% and $20.6 \%$, respectively). As a consequence, all the flows at these two levels show contributions from Manila clams that are as high as $18.5 \%$ of the respiration and $59.4 \%$ of the catches (both at TL II). The contribution of this species to the flows and biomasses at TL IV are relatively low, except for the flow to detritus (15.1\% of the total flow from TL IV to D).

The MTI analysis (Fig. 2) indicated that the artisanal fishery has strong negative impacts on the exploited groups and has slight positive impact on benthic detritivores and mixed feeders. These latter groups are captured by the artisanal fishery, which directly impacts them negatively, but this detrimental effect is overshadowed by positive indirect influences (Ulanowicz and Puccia 1990) resulting in a slightly positive net impact (0.03). The clam fishery (which is split between catch and resuspension effects) has positive impacts on several low trophic level groups, such as suspended organic matter (impact of clam fishery on SOM\&LOM, +0.12), juvenile seabream, juvenile mullets, plankton groups, benthic plants and juvenile T. philippinarum (0.02). The positive impact of the resuspension slightly lessens the negative impact of the fishery on adult clams $(-0.46)$. 

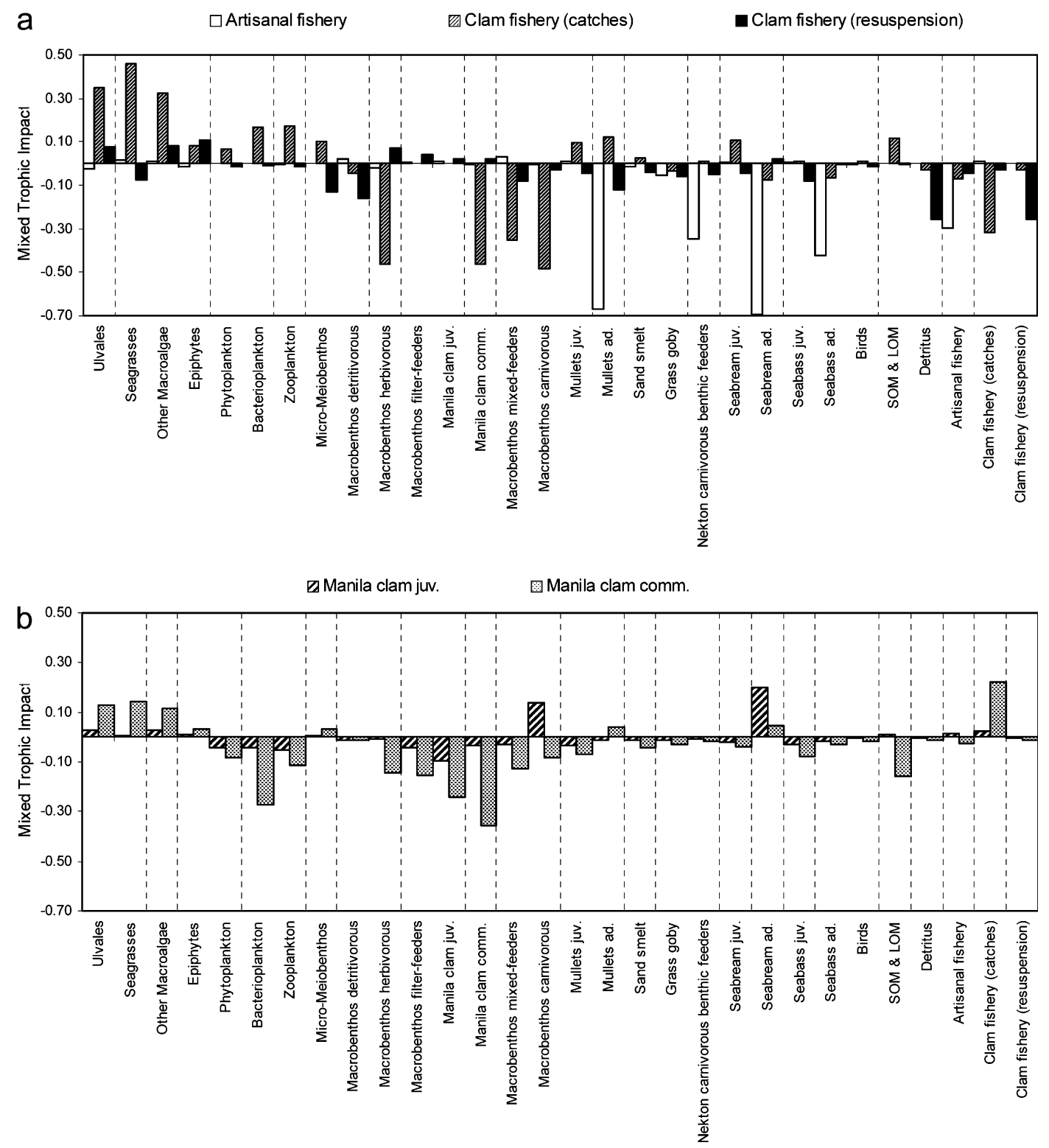

Fig. 2 a Predicted trophic impacts of the fisheries on biota, detritus and fisheries in the Venice lagoon. Effects of clam catches (dashed bars) and resuspension (black bars) are considered separately. b Impacts of juvenile (dashed) and commercial-sized (dotted) Manila clams (Tapes philippinarum) in the ecosystem (SOM\&LOM suspended and labile organic matter)

Figure 3 shows the impact (positive or negative) of a group on the whole system, which is estimated by using the weighted sum of MTIs. The single Manila clam species (considering both juveniles and adults) ranks among the most negatively impacting groups in the system, together with the macrobenthic filter feeders.

The global indices for the past, present and future models are reported in Table 2. Most of the indices indicated minima in the present model, indicating poor health and maturity. Production and respiration were the exceptions, being better balanced in the present scenario, as indicated by the lower NP $(15.2 \%$ of TST for 1998 , while $28.5 \%$ and $19.7 \%$ are estimated for 1988 and 2008 , respectively) and the lower $\mathrm{P} / \mathrm{R}$ ratio (2.33 against 4.21 and 2.75).

The mean trophic level of catches (mTL) is lowest in the present-day model $(\mathrm{mTL}=2.31)$. It is a full trophic level higher in the past and future models $(\mathrm{mTL}=3.27$ and 3.36, respectively), as catches of Manila clam are very low in those scenarios. A more interesting trend of the $\mathrm{mTL}$ is related to the catches of the artisanal fishery only (Table 3). The trophic level of the catch of this fishery shows a similar trend with a minimum in 1998 $(\mathrm{mTL}=3.24)$ and a maximum in the scenario proposed for the future (3.36), a little above the past value (3.31). Table 3 shows the total catches for the artisanal fishery in the three considered models. Landings are predicted to increase from the present scenario $\left(15.17 \mathrm{~kJ} \mathrm{~m}^{-2}\right.$ year $\left.{ }^{-1}\right)$ to the future scenario $\left(20.11 \mathrm{~kJ} \mathrm{~m}^{-2}\right.$ year $\left.^{-1}\right)$, if we remove clam dredging and maintain the present artisanal fishing effort. Total catches of this fishery reach the highest value $\left(22.53 \mathrm{~kJ} \mathrm{~m}^{-2}\right.$ year $\left.^{-1}\right)$ in the 1988 
Table 2 Summary of the indices given by Ecopath for the three models (past, present and future). Most of these indices show a concave trend in which the maximum or minimum is represented by the year 1998, indicating that the system returns to a previous, better state after the reduction of mechanical clam harvesting to zero. However, reconstruction of the past situation is not completely possible as the past ecosystem status always appears to be better

\begin{tabular}{|c|c|c|c|c|}
\hline & Unit & 1988 & 1998 & 2008 \\
\hline \multicolumn{5}{|l|}{ Ecosystem theory indices } \\
\hline Sum of all consumption & $\%$ TST & 23.05 & 30.36 & 29.60 \\
\hline Sum of all respiratory flows & $\%$ TST & 8.87 & 11.43 & 11.26 \\
\hline Sum of all flows into detritus & $\%$ TST & 46.19 & 42.22 & 42.47 \\
\hline Total system throughput (TST) & $\mathrm{kJ} \mathrm{m}^{-2}$ year $^{-1}$ & 400,969 & 99,998 & 85,962 \\
\hline Sum of all production & $\%$ TST & 42.88 & 34.74 & 38.79 \\
\hline Calculated total net primary production (NPP) & $\%$ TST & 37.34 & 26.59 & 30.94 \\
\hline Total primary production/total respiration $(\mathrm{P} / \mathrm{R})$ & & 4.21 & 2.33 & 2.75 \\
\hline Net system production (NP) & $\%$ TST & 28.48 & 15.16 & 19.68 \\
\hline Total primary production/total biomass $(\mathrm{Pp} / \mathrm{B})$ & & 11.34 & 9.87 & 9.92 \\
\hline Total biomass/total throughput (B/T) & & 0.033 & 0.027 & 0.031 \\
\hline Total biomass (excluding detritus) (B) & $\mathrm{kJ} \mathrm{m} \mathrm{m}^{-2}$ & 13,202 & 2,695 & 2,682 \\
\hline Ascendency relative to capacity & $\%$ & 33.40 & 24.80 & 35.40 \\
\hline Overhead absolute & Flowbit & $1,049,216.1$ & 10,293 & $236,518.6$ \\
\hline Overhead relative to capacity & $\%$ & 66.60 & 75.20 & 63.20 \\
\hline Capacity absolute & Flowbit & $1,576,420.2$ & $13,679.8$ & $374,318.3$ \\
\hline \multicolumn{5}{|l|}{ Network analysis indices } \\
\hline Throughput cycled (excluding detritus) & $\mathrm{kJ} \mathrm{m}^{-2}$ year $^{-1}$ & $1,021.51$ & 273.88 & 196.06 \\
\hline Predatory cycling index & $\% \mathrm{TST}^{\circ}$ & 2.06 & 1.54 & 1.32 \\
\hline Throughput cycled (including detritus) & $\mathrm{kJ} \mathrm{m}^{-2}$ year $^{-1}$ & 1.64 & 1.75 & 1.45 \\
\hline Finn's cycling index & $\%$ TST & 15.51 & 16.24 & 15.69 \\
\hline Finn's mean path length & & 3.25 & 3.5113 & 3.5799 \\
\hline Finn's straight-through path length & Without detritus & 0.852 & 1.4318 & 1.6346 \\
\hline Finn's straight-through path length & With detritus & 2.746 & 2.9411 & 3.0181 \\
\hline
\end{tabular}

model, but are at a lower mTL than the future scenario. Trends for the monetary value of landings for the artisanal fishery in the three scenarios (Table 3) were calculated using market prices (for the 2008 we used the prices of 1998). The total monetary value shows a similar trend to that of catches, with the maximum in the past $\left(1988\right.$, about $36,000 € \mathrm{~km}^{-2}$ ), the minimum in the present scenario (about 20,000€ $\mathrm{km}^{-2}$ ), and an increase in value from 1998 to $2008\left(29,000 € \mathrm{~km}^{-2}\right)$. Although the catch increase in the future scenario is predicted to be about $+33 \%$, the monetary value of these catches shows an increase of about $+49 \%$. The proportionally higher increase in value results from increased landings

Table 3 Analysis of mean trophic level $(T L)$ of artisanal fishery catches, quantities and monetary values. Reducing clam harvesting to zero with constant artisanal fishery effort led to the predicted values

\begin{tabular}{cccc}
\hline Year & $\begin{array}{l}\text { Mean TL of } \\
\text { artisanal catches }\end{array}$ & $\begin{array}{l}\text { Artisanal catches } \\
\left(\mathrm{kJ} \mathrm{m}^{-2} \text { year }^{-1}\right)\end{array}$ & $\begin{array}{l}\text { Monetary value } \\
\left(\mathrm{EURO} \mathrm{km}^{-2}\right)\end{array}$ \\
\hline 1988 & 3.31 & 22.5 & 36,217 \\
1998 & 3.24 & 15.1 & 19,667 \\
2008 & 3.36 & 20.1 & 29,253 \\
\hline
\end{tabular}

of more valuable species (which also often have higher TL).

\section{Discussion}

An external energetic input of about $11,000 \mathrm{~kJ} \mathrm{~m} \mathrm{~m}^{-2}$ year $^{-1}$ is required to balance the Ecopath model of Venice lagoon, due to the huge amount of energy required to sustain the clam biomass (Libralato et al. 2002). Furthermore, Sorokin and Giovanardi (1995) suggested that the concentration of suspended food in Venice lagoon occasionally falls below the threshold demanded by Manila clams (Tapes philippinarum). Sampling and experimental data indicate that clam harvesting resuspends about $19,000 \mathrm{~kJ} \mathrm{~m}^{-2}$ year $^{-1}$ of bottom sediment and associated organic carbon, which becomes available to filter feeders (Da Ponte 2001; Pranovi et al. 2001). The composition of this organic carbon pool was not investigated, but Sorokin and Giovanardi (1995) showed that $T$. philippinarum utilises a wide trophic spectrum, including benthic diatoms, detritus and dissolved organic matter, unlike the autochthonous species $T$. decussatus. Consumption of this organic carbon could explain the "Tapes paradox", 


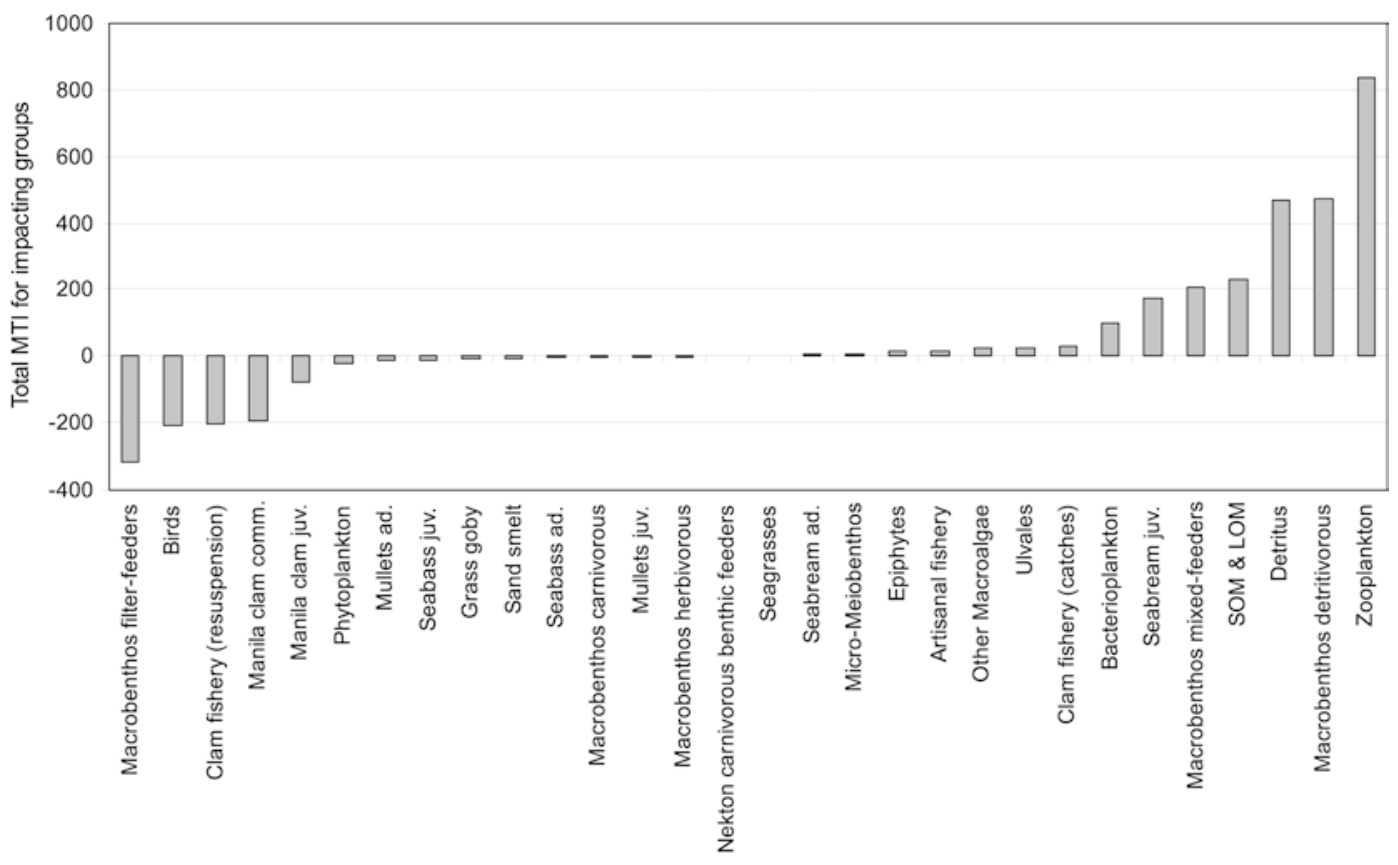

Fig. 3 Total predicted impact of each impacting group on all the impacted groups. Values were obtained by adding the mixed trophic impacts for each impacting group, weighted by the inverse of the biomass of impacted groups. Values are ordered from the most negative to the most positive, and they represent predicted change of the biomass of all groups due to a unit change of the biomass of the impacting group (MTI mixed trophic impact; $S O M \& L O M$ suspended and labile organic matter)

which is the apparent benefit to Tapes populations of exploitation. The species is more abundant in fishing grounds (Casale et al. 2001) than elsewhere, and it shows no signs of overexploitation in spite of the high fishing effort.

A positive feedback between dredging and clam growth seems to be the only reasonable explanation for the simulated Tapes biomass declines of about $20 \%$ in the 2008 scenarios, when the clam fishing effort is reduced to zero. This positive effect of dredging seems to cease at a fishing effort value of about 1.2 times the 1998 levels, after which increased effort does not produce increased captures. This positive feedback makes it possible to consider the harvesting action as a sort of "beneficial top predator" (Ulanowicz and Puccia 1990).

The large amount of filter feeders in the present system (double the biomass of 1988) induces a strong coupling between the pelagic and benthic subsystems. As a consequence, the pelagic system could be strongly affected by the large flux of organic matter from the water column to the benthos (Prins et al. 1998). In cases of strong coupling, the top-down control of phytoplankton biomass by bivalve grazers implies that the bottom-up control of phytoplankton development (i.e. nutrient loading) becomes less important and the ecosystem could be more resilient to changes in external nutrient loading (Herman and Scholten 1990; Prins et al. 1998). In Venice lagoon, this effect could be re-enforced by the constant removal of Tapes biomass by harvesting, which would tend to prevent bottom sediment from excessive accumulation of organic matter and nutrients.

The role of Tapes in the lagoon ecosystem strongly resembles a "wasp-waist control" situation. Wasp-waist species occupy intermediate trophic levels and provide important links between lower and higher trophic levels, indicated by high-energy throughput compared to the other groups at a similar trophic level. In a wasp-waist system, a great portion of the primary production (about 15-30\%) is required to sustain the "central component". As a true wasp-waist species according to this criterion (cf. Benguela system; Shannon et al. 2000), Tapes exerts a strong top-down control of plankton groups. This is highlighted by the mixed trophic impact analysis which showed a Tapes-negative impact on all plankton groups and a positive effect on plankton by clam harvesting - the main "predator" of Tapes. Moreover, the clam fishery produces positive effects on macro-phytal compartments, since it indirectly "controls" grazers (herbivorous and omnivorous mixed feeders), and it has negative impacts on overall benthic compartments and benthic-feeding fishes (such as Zosterisessor ophiocephalus and Sparus auratus) due to negative effects on their prey. It also produces positive effects on SOM\&LOM and negative effects on the artisanal fishery.

Resuspension by mechanical harvesting produces positive effects on $T$. philippinarum, the target species, driven by the effects on resuspended sediment, perhaps mostly due to the positive effect on juveniles. Thus, the MTI analysis gave a quantified representation of the "Tapes paradox" (Libralato et al. 2002), e.g. exploitation activities have a positive effect on the exploited resources. Moreover, the dredging activity produces negative effects on benthic invertebrates (mixed feeders, 
predator and herbivorous) and on detritivorous fish, such as Mugilidae. The negative effect on detritus is compensated by the inverse (detritus-fishery) positive effects.

Mechanical clam harvesting also influences sediment biogeochemistry. On the one hand, the harvesting action removes potential bioturbators (namely large benthic fauna), which mix the sediment and enhance porewater exchange with the overlying water column; on the other hand, it produces a strong physical mixing force itself. Benthic macrofauna usually include bioturbators, and their presence in the system may be integral to maintaining carbon mineralisation and sediment fluxes, allowing non-biochemically mediated oxidation of chemicals, sediment oxygenation, and efficient utilisation of sediment organic material by the community (Krantzenberg 1985; Duplisea et al. 2001). Comparing the three system states indicates a decrease of potential bioturbator biomass from $1988\left(678.3 \mathrm{~kJ} \mathrm{~m}^{-2}\right)$ to 1998 $\left(392.6 \mathrm{~kJ} \mathrm{~m}^{-2}\right)$, the lowest value $\left(351.9 \mathrm{~kJ} \mathrm{~m}^{-2}\right)$ was predicted for 2008, mainly due to the reduction of Tapes biomass. Such reductions of bioturbators could strongly affect nutrient cycling and carbon mineralisation. These processes are directly modified by the suspending/ remixing effect of dredging, which suddenly releases nutrients to the overlying water.

As stated by Vasconcellos et al. (1997), recycling of organic matter is the "chief positive feedback mechanism that contributes to stability in mature systems by preventing overshoots and destructive oscillations due to external impacts", and Finn's indices of cycling and path length seem to be negatively correlated to recovery time. This means that systems in which recycling is important (such as coastal lagoons) appear more stable, or that systems with a higher capacity to recycle (detritus) are more able to resist perturbations.

However, while the internalisation of energy by recycling theoretically increases resistance to change (i.e. increases stability), the lack of redundancy in the recycling pathways could make it very difficult for a highly organised system to re-establish broken pathways (Ulanowicz and Wulff 1991). This could be referred to as the "cost of stability" (Holling 1973).

When categorising the thermodynamic indices (sensu Vasconcellos et al. 1997) our three states are equivalent in terms of complexity of community structure (system omnivory index and number of compartments), but this was expected due to non-independence in the model-building process, i.e. they show the same community structure. In terms of community energetics (PP/B, P/R, B/T, NPP and NP), the 1988 model shows higher values than the others. This is probably due to high seaweed biomass in the 1988 model. Indeed, the comparison between the pre-clam-harvesting scenarios and the present situation shows a dramatic reduction of macroalgae (Ulva rigida and others), which we believe is at least partly due to the high clam fishing activity and decreases in water transparency and light transmittance. The macroalgal decline has been observed since the beginning of the 1990s in the whole lagoon environment, both within and outside clam fishing grounds (Sfriso and Marcomini 1996). This phenomenon could also be driven by the co-occurrence of natural long-term cycles and secondary effects of the fishing activity, as discussed above.

In terms of overall community homeostasis, the 1998 status seems to be less "mature" (e.g. ascendency and overhead), despite slightly higher values of the Finn's cycling indiex (FCI). This is consistent with the idea that perturbed systems tend to do more recycling (Vasconcellos et al. 1997), and, as suggested by Baird et al. (1991), FCI is inversely related to ascendency. The high recycling activity of the 1998 model state could be due to the high mortality and the "quickened" detritus recycling induced by the mechanical harvesting. The present state is, thus, less mature than the "pre-harvesting" state, but more efficient in recycling.

Moreover the positive feedback of resuspension stabilises the system, if clam dredging is considered part of the "ecosystem". Removing clam dredging is, in fact, one way to gain insight into whether the system is "locked in" to an alternative stable state. The results obtained indicate that the system would change if clam dredging were eliminated. This indicates emergent instability: if clam harvesting is not part of the system, Tapes ceases to play its wasp-waist role and this destabilises the entire ecosystem. Such questions could be pursued by combining direct empirical studies, e.g. designing experimental closures, with this type of modelling.

In the 1998 scenario, the total catch is about 20 -fold higher than those obtained for 1988 and 2008, being dominated by Tapes landings. However, the 2008 scenario indicates a 33\% increase of artisanal fishery catch even with no change in artisanal fishing effort. In economic terms, this increase results in a growth of the landing value of about $49 \%$ (from 20,000 to $29,000 €$ $\mathrm{km}^{-2}$ ). Although this increase is low compared with the value of the clam landings (estimated as $480,000 € \mathrm{~km}^{-2}$ for 1998), it represents a positive effect to consider when evaluating management strategies for the clam fishery. The costs encountered by the Italian authorities to restore the lagoon bottom morphology altered by rusca dredging activity (evaluated at about $3 \times 10^{6} €$ year $^{-1}$; Provincia di Venezia 2000) must also be considered. Another interesting trend is shown by the mean trophic level of total catches (artisanal and clam fisheries combined) or the artisanal fishery catch: the lowest value is obtained for the 1998 total catch data. The highest mTL is predicted for the 2008 state, with the cessation of clam harvesting (and resuspension fishery), since this activity causes negative impacts on almost all fish species, as indicated by the MTI analysis.

The described 2008 scenario represents a particularly desirable situation: the elimination of such a deleterious fishery could increase artisanal fishery landings, the mTL of the catches and the monetary value of the fishery. 
In conclusion, this modelling approach to the study of the clam harvesting grounds in Venice lagoon has shown its appropriateness to describe the far-reaching modifications induced, at an ecosystem level, by the introduction and strong proliferation of an invasive species, in terms of system maturity, recycling and potential loss of resilience.

In terms of the future, the 2008 simulation indicated that a gradual cessation of clam fishing effort over 10 years would not produce full system recovery, but it would improve the general features of the system, in comparison with its present degraded state.

Moreover, this modelling approach has shown a peculiar relationship between the fishing activity and its target species: clam dredging appears to enhance the system metabolism and population of the target clam due to resuspension of organic material, which the clam ultimately ingests. This increased food by resuspension is suggested as the solution of the "Tapes paradox".

The evidence and simulations presented here strongly illustrate the need for a clam harvesting management plan for Venice lagoon. They also indicate the potential positive effects of such management strategies on the artisanal fishery, on the mean trophic level and monetary value of the catches and on the whole lagoon ecosystem.

Acknowledgements We thank T. Okey, University of British Columbia-Fisheries Centre, for the critical revision of the manuscript and for his suggestions. We thank also D. Duplisea and another anonymous referee for the constructive critique that improved this article.

\section{References}

Arias A (1980) Crecimiento, regimen alimentarioy reproduccion de la dorada (Sparus aurata L.) y del robalo (Dicentrarchus labrax L.) en los esteros de Cadiz. Investig Pesq 44:59-83

ASAP (Azienza Speciale Acquacoltura e Pesca) (1999) Studio per la razionalizzazione delle attività di pesca e di molluschicoltura nel bacino di Chioggia, laguna di Venezia. ASAP, Venice

Auteri R, Abella A, Baino R, Righini P, Serena F, Silvestri R, Voliani A (1993) Interazioni trofiche e attività di pesca nella laguna di Orbetello. Cons Reg Idrobiol Pesca 6:1-222

Baird D, McGlade JM, Ulanowicz RE (1991) The comparative ecology of six marine ecosystems. Philos Trans R Soc Lond B Biol Sci 333:15-29

Barbaro A, Francescon A, Guidastri R (1983) Allevamento in una valle da pesca della laguna veneta di Sparus aurata L. ottenuta per riproduzione artificiale. Nova Thalassia 6:281-286

Botsford W, Castilla JC, Peterson CH (1997) The management of fisheries and marine ecosystems. Science 277:509-515

Brey T (1990) Estimating productivity of macrobenthic invertebrates from biomass and mean individual weight. Meeresforschung 32:329-343

Buia MC, Gambi MC, Zupo V (2000) Structure and functioning of Mediterranean seagrass ecosystems: an overview. Biol Mar Mediterr 7:167-190

Caddy JF, Cochrane KL (2001) A review of fisheries management past and present and some future prospectives for the third millennium. Ocean Coast Manag 44:653-682

Carrer S, Opitz S (1999) Trophic network model of a shallow water area in the northern part of the lagoon of Venice. Ecol Model 124:193-219
Casale M, Giovanardi O, Grimm F, Orel G, Pessa G (2001) Distribuzione ed abbondanza delle principali specie di molluschi bivalvi nella Laguna di Venezia nell'estate 1999, con particolare riguardo per Tapes philippinarum (Adams and Reeve, 1850). Biol Mar Mediterr 8:413-423

Ceretti G, Ferraresi U, Francescon A, Barbaro A (1987) Chironomids (Diptera: Chironomidae) in the natural diet of gilthead seabream (Sparus aurata L.) farmed in the Venice lagoon. Entomol Scand Suppl 29:289-292

Cesari P, Pellizzato M (1985) Molluschi pervenuti in laguna di Venezia per apporti antropici volontari o casuali. Acclimazione di Saccostrea commercialis (Iredale e Rougley, 1933) e di Tapes philippinarum (Adams e Reeve, 1850). Boll Malacol 21:237-274

Christensen V (1995) Ecosystem maturity, towards quantification. Ecol Model 77:3-32

Christensen V, Pauly D (1993) Trophic models of aquatic ecosystems. ICLARM (Int Cent Living Aquat Resour Manag) Conf Proc 26:390

Christensen V, Pauly D (1998) Changes in models of aquatic ecosystem approaching carrying capacity. Ecol Appl 8[Suppl]:104109

Christensen V, Walters CJ (2000) Ecopath and Ecosim: methods, capabilities and limitations. In: Pauly D, Pitcher TJ (eds) Methods for assessing the impact of fisheries on marine ecosystems of the North Atlantic. Fish Cent Res Rep 8:79-105

Christensen V, Walters CJ, Pauly D (2000) Ecopath 4 user manual. UBC and ICLARM, Vancouver

Christian RR, Fores E, Comin F, Viaroli P, Ferrari I (1993) Comparative network analysis of the nitrogen cycling in several eutrophic coastal ecosystems. In: Guerrero R, Pedros-Alio C (eds) Trends in microbial ecology. Spanish Society for Microbiology, Madrid, pp 449-452

Cloern JE (2001) Our evolving conceptual model of the coastal eutrophication problem. Mar Ecol Prog Ser 210:223-253

Da Ponte (2001) La pesca a strascico come fattore di disturbo ecologico in Laguna di Venezia e in alto Adriatico. MSc thesis, University of Venice, Venice

Dayton PK, Tegner MJ, Edwards PB, Riser KL (1998) Sliding baselines, ghosts, and reduced expectations in kelp forest communities. Ecol Appl 8:309-322

Duffy JE (2002) Biodiversity and ecosystem function: the consumer connection. Oikos 99:201-219

Duplisea DE, Jennings S, Malcom SJ, Parker R, Sivyer B (2001) Modelling potential impacts of bottom trawl fisheries on soft sediment biogeochemistry in the North Sea. Goechem Trans $14: 1-6$

Finn JT (1976) Measures of ecosystem structure and function derived from analysis. J Theor Biol 56:363-380

Flindt M, Salomonsen J, Carrer M, Bocci M, Kamp-Nielsen L (1997) Loss, growth and transport dynamics of Caetomorpha aerea and Ulva rigida in the lagoon of Venice during an early summer field campaign. Ecol Model 102:133-141

Fox JW, Olsen E (2000) Food web structure and the strength of transient indirect effects. Oikos 90:219-226

Francescon A, Barbaro A, Antonini G (1986) Alimentazione ed acrescimento dell'orata (Sparus aurata L.) in valli da pesca del nord Adriatico. Agric Ital (Pisa) 60:7-12

Froese R, Pauly D (2003). FishBase. Available via World Wid Web http://www.fishbase.org. Version Nov 2001

Goulletquer P, Heral M, Deslous-Paoli JM, Prou J, Garnier J, Razet D, Boromthanarat W (1989) Ecophysiologie et bilan energetique de la palourde japonaise d'elevage Ruditapes philippinarum. J Exp Mar Biol Ecol 132:85-108

Granzotto A, Franzoi A, Longo A, Pranovi F, Torricelli P (2000) La pesca nella laguna di Venezia: un percorso di sostenibilità nel recupero delle tradizioni- - lo stato dell'arte. Repporto sullo Sviluppo Sostenibile 2.2001, Fondazione ENI Enrico Mattei

Herman PMJ, Scholten H (1990) Can suspension-feeders stabilize estuarine ecosystems? In: Barnes M, Gibson R (eds) Trophic relationships in the marine environment. Aberdeen University Press, Aberdeen, pp 104-116 
Holling CS (1973) Resilience and stability of ecological systems. Annu Rev Ecol Syst 4:1-23

Jackson J (2001) What was natural in the coastal oceans? Proc Natl Acad Sci USA 98:5411-5418

Jackson J, Kirby MX, Berger WH, Bjorndal A, Botsford LW, Bourque BJ, Bradbury RH, Cooke R, Erlandson J, Estes J, Hughes TP, Kidwell S, Lange C, Lenihan HS, Pandolfi JM, Peterson CH, Steneck RS, Tegner MJ, Warner RR (2001) Historical overfishing and the recent collapse of coastal ecosystems. Science 293:629-638

Jennings S, Pinnegar JK, Polunin NVC, Warr KJ (2001) Impacts of trawling disturbance on the trophic structure of benthic invertebrate communities. Mar Ecol Prog Ser 213:127-142

Jørgensen SE (1992) Integration of ecosystem theories: a pattern. Kluwer, Dordrecht

Kinzing AP, Pacala SW, Tilmann D (eds) (2002) The functional consequences of biodiversity. Empirical progress and theoretical expectations. Princeton University Press, Princeton, N.J.

Krantzenberg G (1985) The influence of bioturbation on physical, chemical and biological parameters in aquatic environments: a review. Environ Pollut Ser A Ecol Biol 39:99-122

Laureau M, Naeem S, Inchausti P (2001) Biodiversity and ecosystem functioning: current knowledge and future challenges. Science 294:804-808

Libralato S, Pastres R, Pranovi F, Raicevich S, Granzotto A, Giovanardi O, Torricelli P (2002) Comparison between the energy flow networks of two habitats in the Venice lagoon. Mar Ecol 23:228-236

Menge BA (1995) Indirect effects in marine rocky intertidal interaction webs: patterns and importance. Ecol Monogr 65:21-74

Monaco ME, Ulanowicz RE (1997) Comparative ecosystem trophic structure of three U.S. mid-Atlantic estuaries. Mar Ecol Prog Ser 161:239-254

Müller F (1997) State-of-the-art in ecosystem theory. Ecol Model 100:135-161

Naeem S (2002) Autotrophic-heterotrophic interactions and their impacts on biodiversity and ecosystem functioning. In: Kinzing AP, Pacala SW, Tilmann D (eds) The functional consequences of biodiversity. Empirical progress and theoretical expectations. Princeton University Press, Princeton, N.J., pp 96-119

NRC (National Research Council) (1995) Understanding marine biodiversity: a research agenda for the nation. National Academy Press, Washington, DC

Odum EP (1969) The strategy of ecosystem development. Science 164:262-270

Pauly D, Christensen V, Dalsgaard J, Froese R, Torres F Jr (1998) Fishing down marine food webs. Science 279:860-863

Pinnegar JK, Polunin NVC (1999) Contributions of stable-isotope data to elucidating food webs of Mediterranean rocky littoral fishes. Oecologia 122:399-409

Pinnegar JK, Polunin NVC, Francour P, Badalamenti F, Chemello R, Harmelin-Vivien M-L, Hereu B, Milazzo M, Zabala M (2000) Trophic cascades in fisheries and protected-area management of benthic marine ecosystems. Environ Conserv 27:179-200

Pitcher TJ (2001) Fisheries managed to rebuild ecosystems? Reconstructing the past to salvage the future. Ecol Appl 11:601-617
Pranovi F, Giovanardi O (1994) The impact of hydraulic dredging for short-necked clams, Tapes spp., on an infaunal community in the lagoon of Venice. Sci Mar 58:345-353

Pranovi F, Raicevich S, Da Ponte F, Boscolo R, Franceschini G, Torricelli P, Giovanardi O (2001) Effects of mechanical clam harvesting on bottom sediment in the Venice lagoon. In: 36th CIESM Congress Proceedings. Multiprint, Monaco, p 410

Prins TC, Smaal AC, Dame RF (1998) A review of the feedbacks between bivalve grazing and ecosystem processes. Aquat Ecol $31: 349-359$

Provincia di Venezia (2000) Piano per la gestione delle risorse alieutiche delle lagune della provincia di Venezia. Provincia di Venezia, Venice

Raffaelli DG, Van der Putten W, Persson L, Wardle DA, Petchey O, Koricheva J, Van der heijden M, Mikola J, Kennedy E (2002) Multi-trophic processes and ecosystem functions. In: Loreau M, Naeem S, Inchausti P (eds) Biodiversity and ecosystem functioning. Oxford University Press, Oxford, pp 147154

Sfriso A, Ghetti PF (1998) Seasonal variation in biomass, morphometric parameters and production of seagrasses in the lagoon of Venice. Aquat Bot 61:207-223

Sfriso A, Marcomini A (1996) Decline of Ulva growth in the lagoon of Venice. Bioresour Technol 58:299-307

Sfriso A, Pavoni B, Marcomini A (1989) Macroalgae and phytoplankton standing crops in the central Venice lagoon: primary production and nutrient balance. Sci Total Environ 80:139-159

Shannon LJ, Cury PM, Jarre A (2000) Modelling effects of fishing in the southern Benguela ecosystem. ICES J Mar Sci 57:720-722

Solidoro C, Pastres R, Melaku Canu D, Pellizzato M, Rossi R (2000) Modelling the growth of Tapes philippinarum in the northern Adriatic lagoons. Mar Ecol Prog Ser 199:137-148

Sorokin YI, Giovanardi O (1995) Trophic characteristics of the Manila clam (T. philippinarum Adams \& Reeve, 1850). ICES J Mar Sci 52:853-862

Sorokin YuI, Sorokin PYu, Giovanardi O, Dalla Venezia L (1996) Study of the ecosystem of the lagoon of Venice, with emphasis on anthropogenic impact. Mar Ecol Prog Ser 141:247-261

Sorokin YuI, Giovanardi O, Pranovi F, Sorokin PYu (1999) Need for restricting bivalve culture in the southern basin of the lagoon of Venice. Hydrobiologia 400:141-148

Ulanowicz RE (1986) Growth and development: ecosystems phenomenology. Springer, New York Heidelberg Berlin

Ulanowicz RE, Puccia CJ (1990) Mixed trophic impacts in ecosystems. Coenoses 5:7-16

Ulanowicz RE, Wulff F (1991) Comparing ecosystem structures: the Chesapeake Bay and the Baltic Sea. In: Cole J, Lovett G, Findlay S (eds) Comparative analysis of ecosystems: patterns, mechanisms and theories. Springer, Berlin Heidelberg New York, pp 140-166

Vasconcellos M, Mackinson S, Sloman K, Pauly D (1997) The stability of trophic mass-balance models of marine ecosystems a comparative analysis. Ecol Model 100:125-134

Walters CJ, Christensen V, Pauly D (1997) Structuring dynamic models of exploited ecosystems from trophic mass-balance assessments. Rev Fish Biol Fish 7:139-172

Watson R, Pauly D (2001) Systematic distortion in world fisheries catch trends. Nature 414:534-536 